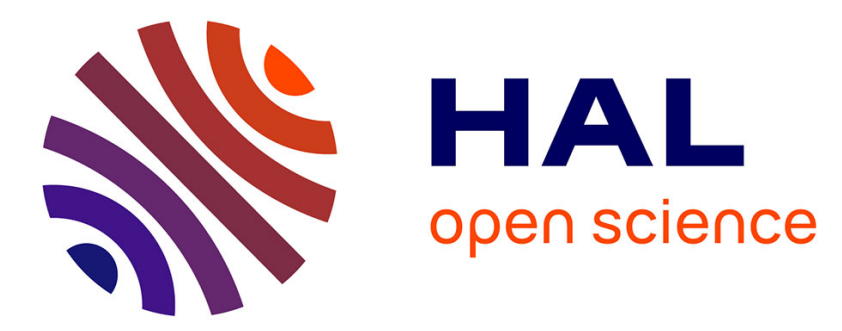

\title{
Sources, distribution and variability of hydrocarbons and metals in atmospheric deposition in an urban area (Paris, France)
}

Sam Azimi, Vincent Rocher, Mathieu Muller, Régis Moilleron, Daniel R. Thevenot

\section{To cite this version:}

Sam Azimi, Vincent Rocher, Mathieu Muller, Régis Moilleron, Daniel R. Thevenot. Sources, distribution and variability of hydrocarbons and metals in atmospheric deposition in an urban area (Paris, France). Science of the Total Environment, 2005, 337, pp.223 - 239. 10.1016/j.scitotenv.2004.06.020 . hal-01086757

\section{HAL Id: hal-01086757 \\ https://hal-enpc.archives-ouvertes.fr/hal-01086757}

Submitted on 24 Nov 2014

HAL is a multi-disciplinary open access archive for the deposit and dissemination of scientific research documents, whether they are published or not. The documents may come from teaching and research institutions in France or abroad, or from public or private research centers.
L'archive ouverte pluridisciplinaire HAL, est destinée au dépôt et à la diffusion de documents scientifiques de niveau recherche, publiés ou non, émanant des établissements d'enseignement et de recherche français ou étrangers, des laboratoires publics ou privés. 


\title{
Sources, distribution and variability of hydrocarbons and metals in atmospheric deposition in an urban area (Paris, France)
}

\author{
Sam Azimi*, Vincent Rocher, Mathieu Muller, Régis Moilleron, Daniel R. Thevenot \\ Centre d'Enseignement et de Recherche sur l'Eau la Ville et l'Environnement (Cereve), Faculté des Sciences et Technologie, \\ Université Paris XII-Val de Marne, 61 Avenue du Général de Gaulle, 94010 Créteil Cedex, France
}

Received 20 October 2003; received in revised form 24 June 2004; accepted 27 June 2004

\begin{abstract}
Total atmospheric deposition, i.e., both wet and dry deposition, was sampled during 11 months in the "Ile-de-France" region, France. Monthly fluxes of aliphatic hydrocarbons (AHs), polycyclic aromatic hydrocarbons (PAHs) and heavy metals (HMs) were studied at three representative sites (two urbanised and one semiurban). A combination of spatial and temporal variability of total fluxes and pollutant fingerprints allows a better understanding of atmospheric pollutant dynamics over this region. In the whole studied area, aggregated total atmospheric fluxes of AHs, PAHs and HMs range from 19 to $33 \mathrm{mg} \mathrm{m}^{-2} \mathrm{y}^{-1}, 99$ to $161 \mu \mathrm{g}$ $\mathrm{m}^{-2} \mathrm{y}^{-1}$ and 48 to $103 \mathrm{mg} \mathrm{m}^{-2} \mathrm{y}^{-1}$, respectively. The highest values are observed in Paris centre, reflecting the importance of the urban centre as a source of pollutants, with a decline in many atmospheric deposits when moving away from urban areas. The seasonal distribution of these pollutants suggests the impact of residential heating on urban atmospheric deposition of hydrocarbons and the increase of dust loads containing HMs during summer. The qualitative study performed on atmospheric deposition data highlights the main sources of pollutants. Aliphatic fingerprints suggest a marked contribution of biogenic inputs to aliphatic contamination in the whole Ile-de-France region and slight petroleum inputs in urban areas. Aromatic fingerprints, characterised by the great predominance of phenanthrene, fluoranthene and pyrene, associated with some specific ratio values, suggest the mixture of petrogenic and pyrolytic contaminations of atmospheric deposition in the whole "Ile-de-France" region. HM distribution shows the presence of anthropogenic sources of $\mathrm{Al}$ and $\mathrm{Fe}$ in this area and the stationary sources (incinerators and plants) as a significant source of $\mathrm{Si}, \mathrm{S}$ and $\mathrm{Sb}$ in the urban atmosphere. Moreover, a pollutant mix phenomenon, occurring in such an urban atmosphere, shows a significant influence on atmospheric deposition at the semiurban site.
\end{abstract}

(C) 2004 Elsevier B.V. All rights reserved.

Keywords: Aliphatic hydrocarbon; PAH; Heavy metal; Fingerprint; Origin

* Corresponding author. Tel.: +331451716 20; fax: +33145 171627.

E-mail addresses: azimi@univ-paris12.fr (S. Azimi), thevenot@univ-paris12.fr (D.R. Thevenot).

\section{Introduction}

Atmospheric pollutants such as aliphatic hydrocarbons (AHs), polycyclic aromatic hydrocarbons 
(PAHs) and heavy metals (HMs) have long been recognised as potential threats to the environment and human health. During the past decades, government efforts to control air pollution have achieved some positive effects, and as a result, atmospheric pollutants have been reduced significantly. In many locations, evidence of the decline in pollutant concentrations has been reported (Azimi et al., 2003; Cortes et al., 2000). However, air pollution is still a major problem and tighter emission controls are being enforced by many governments. The urban atmosphere is subjected to large inputs of anthropogenic contaminants produced by both stationary (power plants, industries and residential heating) and diffuse sources (road traffic; Bilos et al., 2001; Schauer et al., 1996). According to their different physical and chemical properties (vapor pressure, Henry's law constant), the size and composition of the source particles, these pollutants are partitioned between particulate and vapor phases and are subsequently transported to the Earth's surface through dry and wet deposition (Lawlor and Tipping, 2003). From a biogeochemical perspective, the characterisation of total atmospheric deposition is relevant in order to identify the variability and sources of the atmospheric pollutants.

Generally, studies performed on these kinds of pollutants, as PAHs or HMs, determine fluxes at only one site and compare their results with those from other work done in the same areas (Maneux et al., 1999; Ollivon et al., 2002). Such approaches allow an estimation of pollutant spatial variations but may induce much bias because the sampling and analysis techniques are not standardised from one study to another. In this present research program, we measured the hydrocarbon (both the particulate and the soluble fractions of the aliphatic and aromatic com- pounds) and the HM (the acid-soluble fraction) pollution in monthly bulk atmospheric deposition, i.e., dry and wet deposition sampled together. These deposits were sampled over 11 months at three stations situated in a residential area (Paris centre), an industrial suburb sector (Créteil) and a semiurban sector of this region (Coulommiers). The first aim of this work is to determine atmospheric fallout fluxes in order to assess their spatial variability in this area and to estimate their seasonal changes. Secondly, pollutant fingerprints are investigated, using specific ratios, in order to assess their spatial and temporal variability and to elucidate the origin of atmospherically deposited pollutants.

\section{Material and methods}

\subsection{Sites}

This research was performed in the "Ile-de-France" region. This region, which includes Paris City, is the most industrialised and densely populated region of France (11 million inhabitants). It comprises many waste incinerators, power plants, various industrial plants, and especially, heavy road traffic. In order to evaluate the impact of these pollutant sources, three sampling stations were established in a $60-\mathrm{km}$ long NW-SE transect through this region (Fig. 1). The first site, situated in the fourth district of Paris City (PAR, $48^{\circ} 52^{\prime} \mathrm{N}, 2^{\circ} 22^{\prime} \mathrm{E}$ ), was placed on a building flat roof at $18-\mathrm{m}$ height above ground level. Two potential sources may mainly affect the atmospheric deposition there: heavy urban traffic and residential heating. The second site, situated at Créteil (CRE, $48^{\circ} 47^{\prime} \mathrm{N}$, $2^{\circ} 28^{\prime} \mathrm{E}$ ), was placed on the roof of the Paris XII

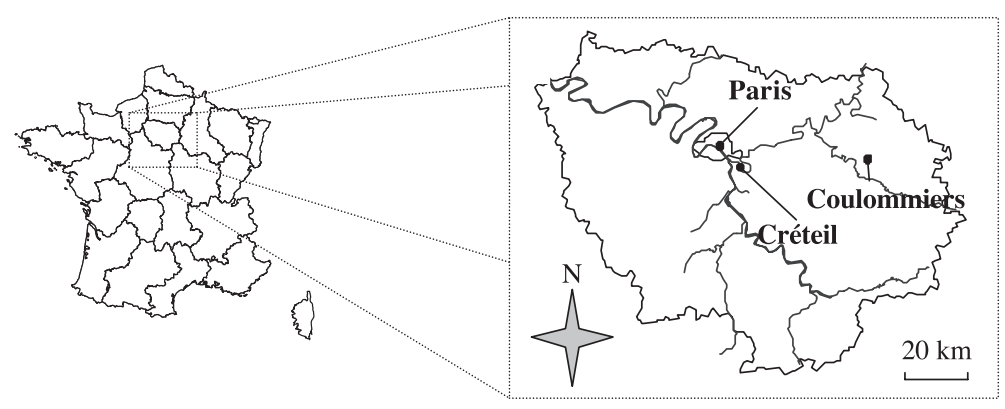

Fig. 1. Location of the three sampling stations established in the "Ile-de-France" region. 
University building at $20-\mathrm{m}$ height above ground level. This area is much industrialised and presents many anthropogenic activities. Indeed, in addition to a heavy traffic highway (A86, $200 \mathrm{~m}$, West, 60,000 vehicles/day), this site is near a power plant $(1900 \mathrm{~m}$, West), two waste incinerators (5700 m, North-West; $500 \mathrm{~m}$, South) and an international airport (Orly, 8400 $\mathrm{m}$, South-West). The third site, situated $50 \mathrm{~km}$ away from Paris near the town of Coulommiers (COU, $48^{\circ} 49^{\prime} \mathrm{N}, 3^{\circ} 05^{\prime} \mathrm{E}$ ), was placed on grassland near agricultural fields. This area, which is far from the main anthropogenic sources, is situated under the plume of the whole urbanised area because the wind mainly blows from the west in this region (Garban et al., 2002; Garnaud et al., 2001) and is defined as a semiurban site.

\subsection{Sampling procedures}

\subsubsection{Hydrocarbons}

Bulk atmospheric deposition (wet and dry) was sampled from December 2001 to October 2002 using pyramid-shaped funnels $(55 \times 55 \times 70 \mathrm{~cm})$ made of stainless steel. These devices collected both dry deposition and precipitation continuously for 6-week periods. The deposits were collected in 25-1 aluminium bottles placed in isothermal boxes made of expanded polystyrene so as to minimise temperature variation and evaporation (Ollivon et al., 2002). The whole equipment reached a height of $150 \mathrm{~cm}$. At the end of each sampling period, the funnels were rinsed with $500 \mathrm{ml}$ of purified water (Milli-Ro 5 Plus, Millipore) in order to release most sorbed particles from the funnel walls. The AHs and PAHs were determined separately in both particulate and dissolved fractions of each sample.

\subsubsection{Heavy metals}

The bulk deposition collectors for HMs consisted of Teflon funnels of collection area of $113 \mathrm{~cm}^{2}$ connected to polyethylene bottles $(51)$. This equipment was placed inside PVC pipes at a height of $190 \mathrm{~cm}$. The sampling period of the total atmospheric deposition was 28 days. The collection bottles were filled before each sampling period with $50 \mathrm{ml}$ of $10 \%$ acidified $\left(\mathrm{HNO}_{3} 65 \%\right.$ Suprapur, Merck) ultra pure water (18,2 $\mathrm{M} \Omega$ Milli-Q water, Millipore). This water layer allowed the dissolution of most particles during the sampling period. At the end of each collection period, funnels were rinsed with $100 \mathrm{ml}$ of $1 \%$ acidified MilliQ water in order to collect particles deposited or sorbed on funnel walls, and both the funnel and the bottle were then replaced by clean ones. Such sampling procedures allowed the dissolution of the acid-soluble fraction of particles which mainly comes from anthropogenic activities (Colin et al., 1990; Desboeufs et al., 2001; Sandroni and Migon, 2002). The crustal elements contained in the insoluble fraction have not been considered in this paper.

\subsection{Analysis procedures}

For hydrocarbons, the particulate fraction was Soxwave extracted by a $\mathrm{CH}_{2} \mathrm{Cl}_{2}-\mathrm{MeOH}$ mixture. The filtered fraction $(<0.45 \mu \mathrm{m})$ was liquid-liquid extracted with $\mathrm{CH}_{2} \mathrm{Cl}_{2}$. After purification and separation into aliphatic and aromatic fractions, both types of subsamples were injected on a GC-MS (1800 A, Hewlett Packard). Hydrocarbons were quantified using a mixture of perdeuterated hydrocarbons added to the samples prior to extraction. For acid-soluble metal fraction, the acidified samples were filtered $(<0.45 \mu \mathrm{m})$ and the filtrate was analysed with an ICPAES Perkin Elmer Optima 3000. Quality control was performed using test samples. The whole analysis procedure is described in detail by Rocher et al. (2003) for hydrocarbons and by Azimi et al. (2003) for metals.

\subsection{Quality control procedures}

\subsubsection{Hydrocarbons}

Each step of the whole procedure has been separately investigated. Laboratory blanks (LB) and field blanks (FB), consisting of a Milli-Q water solution and a prepared bottle filled with Milli-Q water solution transported to the field, respectively, were treated in the same way as samples. In addition, analytical blanks were included. Both laboratory and field blanks were generally between $5 \%$ and $10 \%$ of the concentrations in the samples.

The certified material SRM 1941a (U.S. Department of Commerce, National Institute of Standards and Technology, Gaithersburg, MD 20 899, USA), which presents certified values for aromatic hydrocarbons, was used to evaluate the Soxwave extraction efficiency. Depending upon the hydrocarbon selected, 
the recovery ranged between $58 \%$ and $138 \%$. These results, quite similar to those of Evans et al. (1990), i.e., $83 \%$ and $131 \%$, have been calculated using the indicative values given by NIST. In order to evaluate the liquid-liquid extraction efficiency, we used Florida TPH mix (NSI Environmental Solutions), which is a mixture of 17 dissolved aliphatic hydrocarbons from $\mathrm{C}_{10}$ to $\mathrm{C}_{40}$. The recovery was $96 \pm 15 \%$ (average \pm standard deviation).

\subsubsection{Heavy metals}

The validation procedure for heavy metal determination consists of three steps using laboratory blanks (LB), field blanks (FB) and samples certified for trace metals. $\mathrm{LB}$ were chosen as $1 \%$ nitric acid solution while $\mathrm{FB}$ consisted of $50 \mathrm{ml}$ of a $1 \%$ nitric acid solution transported to the field. Both LB and FB are below the sample concentration values for all heavy metals, except for $\mathrm{Cd}$ and $\mathrm{Cr}$, showing that material cleaning and sampling treatment procedures have no significant effect on heavy metal analysis. So, for $\mathrm{Cd}$ and $\mathrm{Cr}$, we assumed that estimated fluxes are overestimations.

The accuracy of the analytical results was verified using two samples certified in dissolved trace. For some elements $(\mathrm{Cd}, \mathrm{Cu}, \mathrm{Fe}$ and $\mathrm{Na})$, deviations between measured and certified values are less than $10 \%$. In the case of $\mathrm{Pb}$, there is a relatively high deviation between certified and measured values (54\%) for low concentration samples, but this level is 10 times lower than $90 \%$ of the measured values at the Coulommiers site. For other elements, the devia- tion is between $15 \%$ and $25 \%$, but measured concentrations are included in the uncertainty interval given for the certified values. Therefore, analytical conditions are considered as validated for atmospheric trace metal analysis.

\section{Results and discussion}

\subsection{Pollutant fluxes}

Hydrocarbon and metal pollutant fluxes presented in the following sections are calculated by summing pollutant fluxes collected in both the particulate and dissolved fractions for AHs and PAHs and in the acidsoluble fraction for HMs.

\subsubsection{Spatial variability}

Fig. 2 shows the annual deposition fluxes $\left(\mathrm{mg} \mathrm{m}^{-2}\right.$ $\mathrm{y}^{-1}$ ) of hydrocarbon and metal pollutants. For hydrocarbons, aliphatic and aromatic compounds are distinguished. Total AHs are the sum of more than $20 n$ alkanes, i.e., from $n$-C 8 to $n$-C 33 , and two isoprenoids prystane and phytane. Total PAHs are the sum of the 16 PAHs selected from the priority list of the U.S.EPA. For metallic pollutants, $\mathrm{Al}$ and $\mathrm{Fe}$ and trace heavy metals (THMs) are distinguished. The first group ( $\mathrm{Al}$ and $\mathrm{Fe}$ ) fluxes are calculated by the summation of both $\mathrm{Al}$ and Fe fluxes while THM fluxes are the sum of the fluxes of the 13 following elements: $\mathrm{Ba}, \mathrm{Cd}, \mathrm{Co}, \mathrm{Cr}, \mathrm{Cu}, \mathrm{Ni}, \mathrm{Mn}, \mathrm{Pb}, \mathrm{Sb}, \mathrm{Sr}, \mathrm{V}$, Ti and Zn. For each type of pollutant (total AHs, total

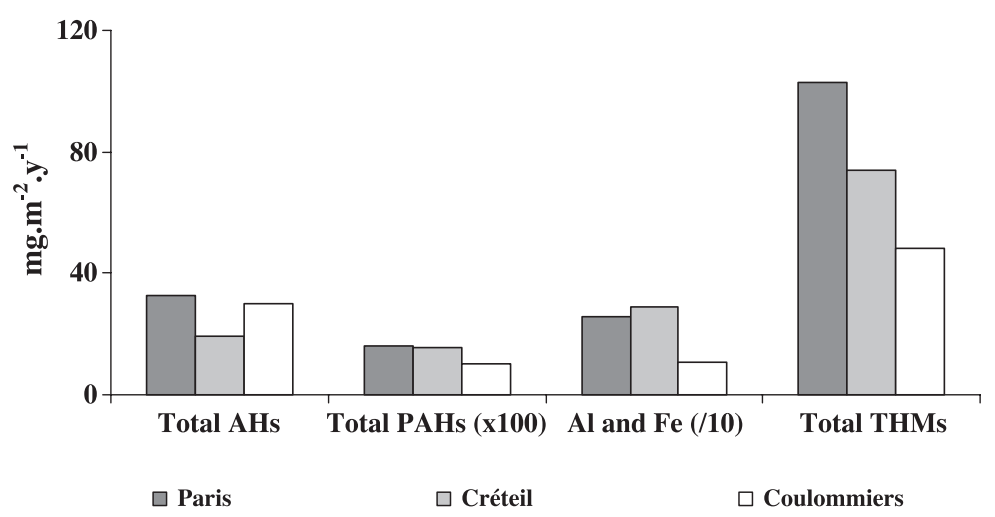

Fig. 2. Annual atmospheric deposition fluxes $\left(\mathrm{mg} \mathrm{m}^{-2} \mathrm{y}^{-1}\right)$ of total AHs, total PAHs, Al and Fe and total THMs measured at Paris, Créteil and Coulommiers. 
PAHs, Al and Fe, total THMs), annual deposition fluxes are calculated by aggregating total deposition fluxes calculated over the whole sampling period.

\subsubsection{Total AHs. Fluxes measured at Paris, Créteil} and Coulommiers reach 33, 19 and $30 \mathrm{mg} \mathrm{m}^{-2} \mathrm{y}^{-1}$, respectively (Fig. 2). The Paris flux level is the highest among the three sites. This result underlines the impact of a densely populated area, including both residential heating and heavy road traffic, on total $\mathrm{AH}$ atmospheric deposition. A similar impact was observed in particulate fallout in Alexandria (Egypt; Aboulkassim and Simoneit, 1995) and in airborne particles in the La Plata area (Argentina; Colombo et al., 1999). The Coulommiers flux level is close to that of Paris. Nevertheless, we assume that, in contrast to the case of Paris, aliphatic hydrocarbons identified in this semiurban site do not originate from anthropogenic activities. Surprisingly, the atmospheric deposition of total AHs at the Créteil site is lower than for Paris, although the sites are only $10 \mathrm{~km}$ apart.

\subsubsection{Total PAHs. The total PAH levels show quite} similar values at both urban sites because the annual deposition fluxes of these pollutants reach 161 and 153 $\mu \mathrm{g} \mathrm{m}^{-2} \mathrm{y}^{-1}$ for Paris and Créteil, respectively (Fig. 2). This deposition level appears to be within the same range as most urban areas. Indeed, Manoli et al. (2002) reported that total PAH fluxes ranged from 73 to 401 $\mu \mathrm{g} \mathrm{m}^{-2} \mathrm{y}^{-1}$, in 1997, in an urbanised site in Northern Greece. Similarly, deposition fluxes of 230 and $363 \mu \mathrm{g}$ $\mathrm{m}^{-2} \mathrm{y}^{-1}$ were observed in Texas and Miami, respectively (Lang et al., 2002; Park et al., 2001). Therefore, total PAH deposition fluxes are similar in several urban areas of the north hemisphere. The annual deposition flux in the semiurban site (Coulommiers) is $100 \mu \mathrm{g} \mathrm{m}^{-2} \mathrm{y}^{-1}$, i.e., $40 \%$ lower at $50 \mathrm{~km}$ from the Paris and Créteil sites. This result reflects the importance of urban areas as a source of PAHs and the decline in PAH deposition outside of urban areas.

3.1.1.3. Al and Fe. Deposition fluxes of $\mathrm{Al}$ and $\mathrm{Fe}$ are very close at both urban sites but lower at the semiurban site (Fig. 2). Values reach 258, 291 and $107 \mathrm{mg} \mathrm{m}^{-2} \mathrm{y}^{-1}$ at Paris, Créteil and Coulommiers, respectively. Similar results were previously obtained in this urban site because Azimi et al. (2003) reported a total $\mathrm{Al}$ and Fe flux of $234 \mathrm{mg} \mathrm{m}^{-2} \mathrm{y}^{-1}$ at Créteil during a 6-month campaign in 2000. The flux determined at the remote site is also in good agreement with the data range reported in the literature, i.e., 33 to $139 \mathrm{mg} \mathrm{m}^{-2} \mathrm{y}^{-1}$ (Azimi et al., 2003; Kim et al., 2000). Therefore, a constant atmospheric deposition flux is observed for at least a 3 -year period. The relative increase of $140 \%$ between Coulommiers and Paris $(170 \%$ between Coulommiers and Créteil) suggests that acid-soluble $\mathrm{Al}$ and $\mathrm{Fe}$ mainly originate from anthropogenic activities. Moreover, the highest flux obtained at Créteil even suggests that these elements are mainly emitted by stationary sources, i.e., waste incinerators or power plants, and not by residential heating or road traffic, which are the main sources in Paris centre.

3.1.1.4. Total THMs. Total annual heavy metal flux at Paris centre is estimated at $103 \mathrm{mg} \mathrm{m}^{-2} \mathrm{y}^{-1}$. This flux is higher by a factor of 1.5 and 2 than those for Créteil and Coulommiers (Fig. 2). Similar flux values have been previously reported in urban areas, ranging from 28 to $131 \mathrm{mg} \mathrm{m}^{-2} \mathrm{y}^{-1}$ (Golomb et al., 1997; Guieu et al., 1997). In contrast, the flux measured at the Coulommiers site is higher than fluxes previously obtained at other rural areas. For examples, values ranging from 27 to $29 \mathrm{mg} \mathrm{m}^{-2} \mathrm{y}^{-1}$ were reported in the North Sea area (Belgium) and near the Great Lakes in the United States of America (Injuk et al., 1998; Sweet et al., 1998). Differences between the three sites (Paris, Créteil and Coulommiers) are probably due to differences in their anthropogenic activities. Presumably, the high density of urban and industrial sources in Paris suburbs is responsible for the high fluxes measured at Paris, and to a lesser extent, at Créteil. Moreover, it seems that the highest flux obtained at the Paris site indicates road traffic and/or residential heating as the main sources of these elements.

\subsubsection{Seasonal variability}

Fig. 3 presents seasonal variations of total AHs, total PAHs, $\mathrm{Al}$ and $\mathrm{Fe}$ and total THMs. Results obtained during 11 months are grouped by season as follows: winter period from December to early March, spring from March to June, summer from early July to September and fall from late September to early November. All quarterly fluxes are calculated for 3month periods whatever the sampling duration. In the following sections, the cold period refers to fall and 


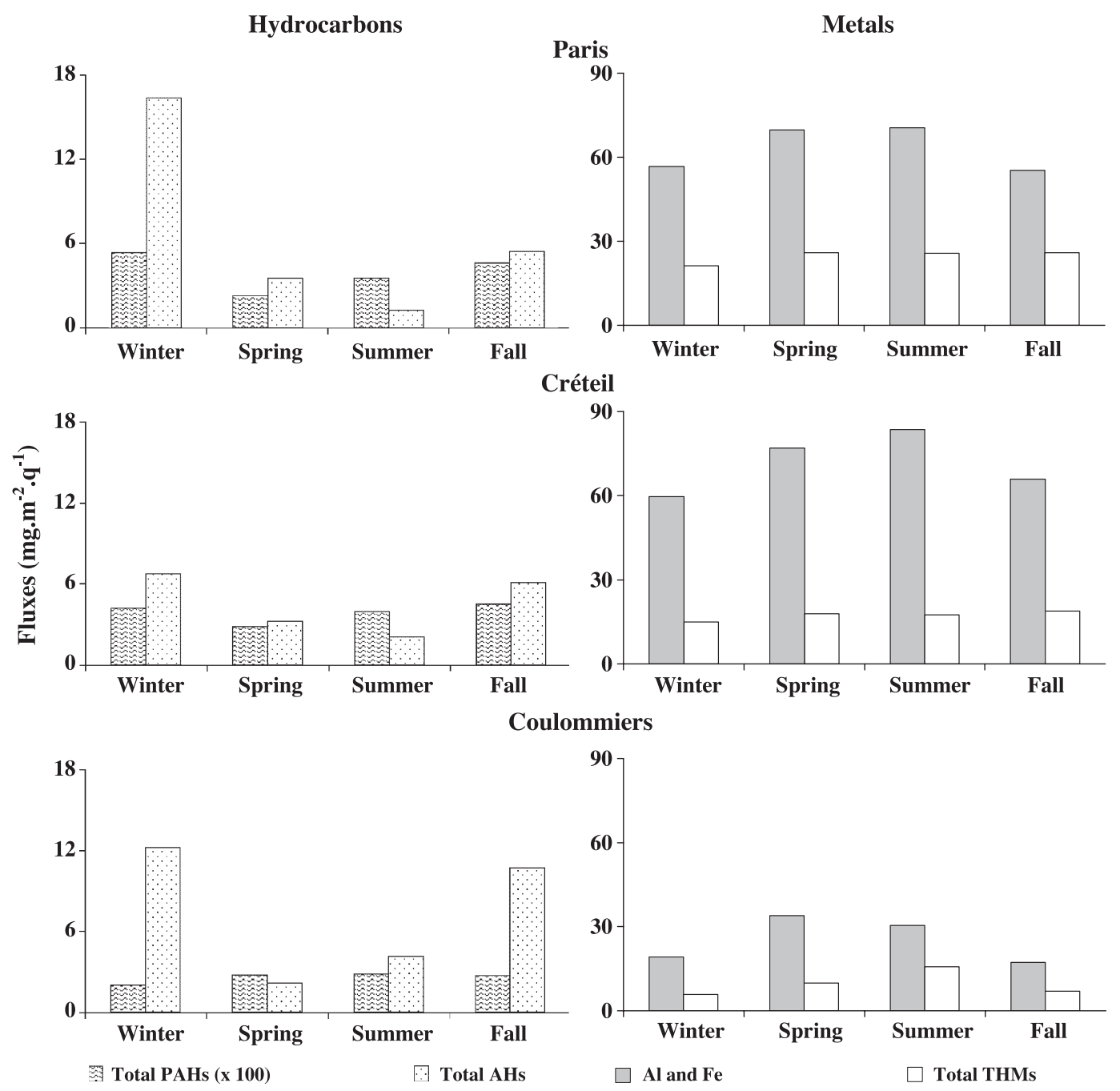

Fig. 3. Quarterly atmospheric deposition fluxes $\left(\mathrm{mg} \mathrm{m}^{-2} \mathrm{q}^{-1}\right)$ of total AHs, total PAHs, Al and Fe and total THMs measured at Paris, Créteil and Coulommiers.

winter quarters and the warm period refers to spring and summer quarters.

3.1.2.1. Total AHs. Similar seasonal trends are observed at the three sites of the Paris suburbs. Indeed, for the three sites, quarterly total $\mathrm{AH}$ fluxes during the cold period, which range from 5.3 to $16.1 \mathrm{mg} \mathrm{m}^{-2} \mathrm{q}^{-1}$, are significantly greater $(99 \%$ confidence level) than those for the warm period, which range from 1.2 to 4.1 $\mathrm{mg} \mathrm{m} \mathrm{m}^{-2} \mathrm{q}^{-1}$ (Fig. 3). Differences are found to be quite important because cold period fluxes are approximately 4.5, 2.5 and 3.6 times higher than those for the warm period at Paris, Créteil and Coulommiers, respectively. Such seasonal variations observed in the Paris area are in good agreement with previous studies carried out in other countries. For example, experiments performed in the metropolitan area of Miami (USA) showed that the winter flux was nearly twice as high as that of summer (Lang et al., 2002).

3.1.2.2. Total PAHs. Similar seasonal trends are observed at both urban sites. Indeed, during the warm period, total PAH fluxes range from 23 to 36 and from 28 to $39 \mu \mathrm{g} \mathrm{m}^{-2} \mathrm{q}^{-1}$ at Paris and Créteil, respectively, 
whereas cold period fluxes range from 46 to 54 and from 42 to $45 \mu \mathrm{g} \mathrm{m}^{-2} \mathrm{q}^{-1}$ at the same sites (Fig. 3). A seasonal difference is observed at both sites because the cold period fluxes of total PAH are 1.5 times greater than those of the warm period. Our study confirms previous results reported for urban sites (Halsall et al., 1997; Ollivon et al., 2002). Because the warm flux is mainly due to vehicular traffic and industrial activities and this flux is nearly steady throughout the whole year, the increase of PAH load in winter - evaluated at $41 \%$ at Paris and $22 \%$ at Créteil-is attributed to residential heating in the Paris area. This result confirms data reported by Ollivon et al. (2002) and Baek et al. (1991) about the contribution of residential heating to atmospheric emissions of total PAHs estimated at: $41 \%$ in France, $36 \%$ in the USA, 26\% in Sweden and $21 \%$ in Norway. The total PAH flux observed at the Coulommiers site shows no clear seasonal variation: the cold period flux ranged from 20 to $27 \mu \mathrm{g} \mathrm{m}^{-2} \mathrm{q}^{-1}$ and that of the warm period from 28 to $28.5 \mu \mathrm{g} \mathrm{m}^{-2} \mathrm{q}^{-1}$. Thus, it appears that residential heating occurring at Coulommiers does not contribute significantly to hydrocarbon atmospheric deposition and the urban heating influence from Paris does not reach this semiurban site.

3.1.2.3. $\mathrm{Al}$ and $\mathrm{Fe}$. Deposition fluxes of $\mathrm{Al}$ and $\mathrm{Fe}$ range between 57 and 70, between 60 and 84 and between 19 and $34 \mathrm{mg} \mathrm{m}^{-2} \mathrm{q}^{-1}$ at Paris, Créteil and Coulommiers, respectively (Fig. 3). For these three sites, a slight increase in $\mathrm{Al}$ and $\mathrm{Fe}$ deposition occurs during the warm period. Indeed, the aggregated fluxes reach 110,120 and $37 \mathrm{mg} \mathrm{m}^{-2}$ during the cold period and 140,160 and $63 \mathrm{mg} \mathrm{m}^{-2}$ during the warm period, at Paris, Créteil and Coulommiers, respectively. Increase factors during the warm period are found to be nearly similar at both urban sites (1.27 and 1.33 at Paris and Créteil) and more important at the semiurban site (1.70 at Coulommiers). This increase is consistent with the observations established during 1990 at three Chesapeake Bay sites (Scudlark et al., 1994) and during 1994 in the North Sea area (Injuk et al., 1998). Higher concentrations of elements may be attributed to the higher loads of atmospheric dusts observed during spring and summer (Kaya and Tuncel, 1997). The rainfall amount and the higher surface moisture levels in fall and winter inhibit the generation of particles by resuspension of dusts.
Although such crustal particles are not totally acidsoluble, they may release $\mathrm{Al}$ and Fe. Therefore, the greater factor of increase observed at Coulommiers could be associated with intensity of soil disturbance related to local agricultural practices.

3.1.2.4. Total THMs. Deposition fluxes of total THM range from 17 to 26 and from 15 to $26 \mathrm{mg} \mathrm{m}^{-2} \mathrm{q}^{-1}$ during warm and cold periods, respectively, at both urban sites (Fig. 3). THMs present a steady atmospheric quarterly flux throughout the year without any significant variation. These elements are mostly (>95\%) non-crustal (Kim et al., 2000). This result is induced by the fact that the major atmospheric sources of THMs, which are non-ferrous metal refining, waste incineration and road traffic (Pacyna and Graedel, 1995), show quite constant emission fluxes throughout the year. At the semiurban site, deposition fluxes of anthropogenic trace elements range from 10 to 16 and from 6 to $7 \mathrm{mg} \mathrm{m}^{-2} \mathrm{q}^{-1}$ during warm and cold periods, respectively. Thus, a seasonal variation appears, characterised by maximum deposition fluxes during the warm period. Such behaviour confirms the soil disturbance at this location. Because anthropogenic activities are less important at Coulommiers, particles originating from resuspension of dust, which is an important source of many trace metals (Sweet et al., 1998), have an important influence on atmospheric deposition.

\subsection{Pollutant fingerprints}

\subsubsection{Hydrocarbon fingerprint variability}

Considering that aliphatic and aromatic hydrocarbon distributions differ according to the production sources, investigation of the spatial and temporal variability of hydrocarbon fingerprints in bulk deposition allows elucidation of their origin. The aliphatic hydrocarbon indexes mainly allow the identification of biogenic and petrogenic sources, while PAH indexes are sensitive indicators of petrogenic and pyrogenic origins. In this section, spatial and temporal variability of hydrocarbon fingerprints is discussed by only taking into account the distribution of the particulate phases of bulk deposition in order to increase graphic readability. This does not induce any information loss because both particulate and dissolved phases show quite similar hydrocarbon fingerprints. 
3.2.1.1. Aliphatic hydrocarbons. As previously mentioned, $n$-alkanes ranging from $n$-C 8 to $n$-C33 and two isoprenoids, pristane and phytane, are quantified.
Fig. 4 presents the relative distribution of $n$-alkanes and isoprenoids in particulate atmospheric fallout collected at the three sites during the winter, spring,
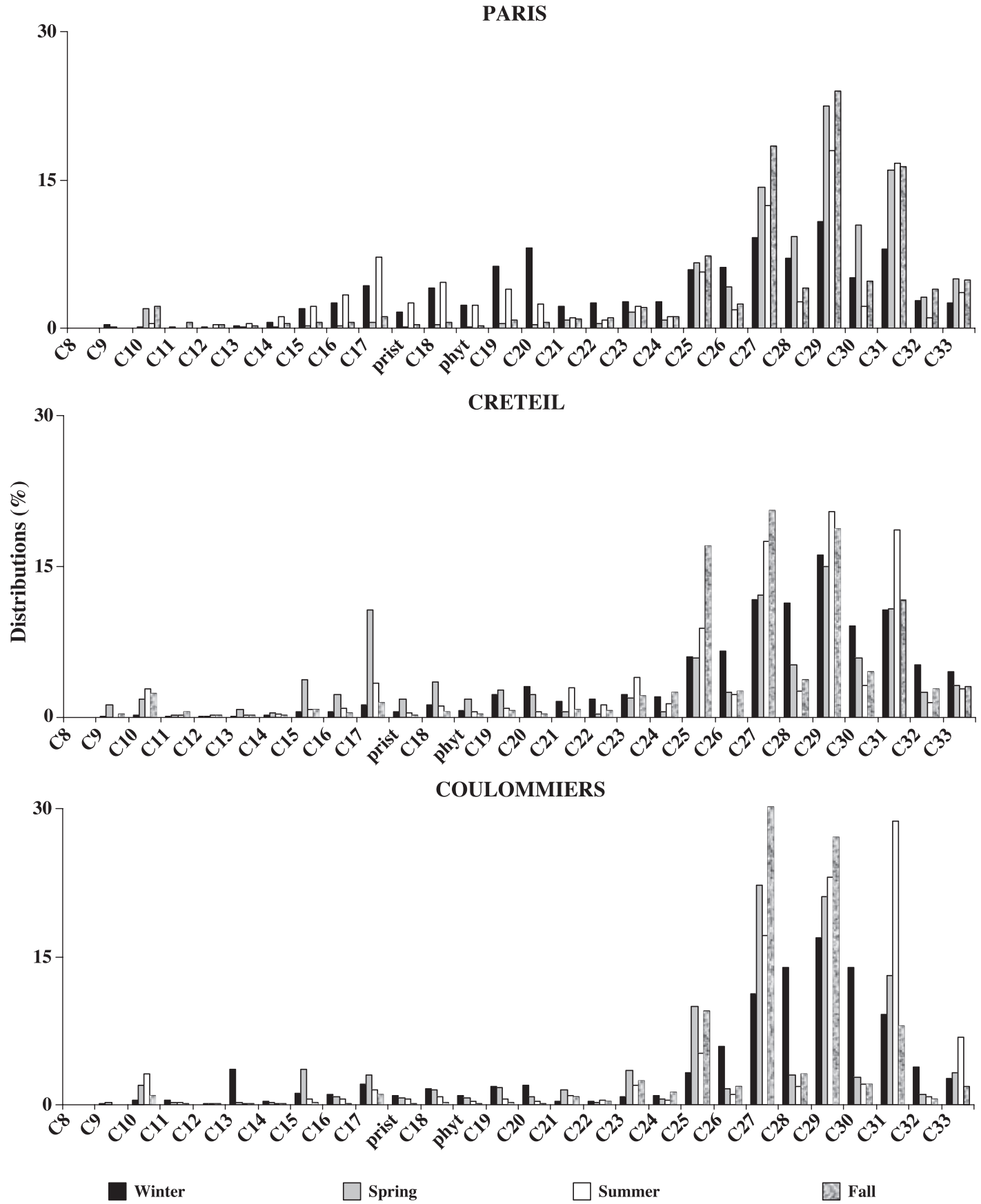

Fig. 4. $\mathrm{N}$-alkane distributions in particulate atmospheric deposition collected at Paris, Créteil and Coulommiers during each season. 
summer and fall periods. Aliphatic distribution patterns are found to be quite similar at all sites: the distribution pattern is bimodal, characterised by a very predominant hump peak at around $n-\mathrm{C} 27 / n-\mathrm{C} 29 / n$ C31 $-n$-C29 being often the major hydrocarbon (Table 1) - and a minor hump centred on $n-\mathrm{C} 17 / n$ C18/n-C20. Predominance of heavy $n$-alkanes (carbon number $>20$ ) is also underlined by the light molecular weight (LMW)/high molecular weight (HMW) ratios which range from 0.04 to 0.5 (Table 1). Abundance of heavy $n$-alkanes and predominance of the $n-\mathrm{C} 29$, illustrated by $n-\mathrm{C} 17 / n-\mathrm{C} 29$ ratios ranging from 0.03 to 0.71 (Table 1), indicate an important biogenic contamination, i.e., terrestrial plants, at both urban and rural sites (Colombo et al., 1989; Moreda et al., 1998). Biogenic origins for aliphatic hydrocarbons can also be demonstrated using the odd/even $n$-alkane predominance. This odd/even predominance can be quantitatively formulated by different specific indexes such as the $n-\mathrm{C} 16$ ratio (sum of $n$-alkanes $/ n$-C16) or the carbon preference index (CPI) defined as the weighted ratio of odd to even carbon-numbered $n$-alkanes in the $n$-C $8-n$ $\mathrm{C} 33$ range. The $n-\mathrm{C} 16$ ratio is usually large (around 50) in biogenic samples because of the dominance of odd $n$-alkanes and is lower (around 15) in petrogenic samples (Colombo et al., 1989). Values of CPI near unity are typical of petrogenic origin, while greater values (i.e., above 3 to 5) indicate a biogenic origin (Bomboi and Hernandez, 1991; Bouloubassi and Saliot, 1993; Wang et al., 1997). Table 1 shows that all bulk deposition samples are characterised by large $n$-alkanes/ $n$-C16 values, i.e., in the 30-201 range, and CPI values above unity. So, odd/even predominance confirms the marked contribution of biogenic inputs to aliphatic hydrocarbon contamination in atmospheric fallout collected at both urban and semiurban sites. This latter result is in good agreement with the literature because many authors have identified biogenic materials - particularly cuticular waxes from vascular plants - as the major component of aerosols collected in urban and rural areas (Gogou et al., 1996; Simoneit et al., 1991). Colombo et al. (1999) even estimated that in urban areas, plant material contributed as much as $34-96 \%$ of the airborne particulate aliphatic hydrocarbons. Nevertheless, aliphatic distributions in bulk deposition collected at both urban sites also reveal an anthropogenic aliphatic hydrocarbon contamination. Indeed, the atmospheric deposition sampled at Paris (winter and summer periods) and Créteil (spring period) exhibits a relatively elevated proportion of $n$-alkanes from $n$-C15 to $n$-C23 (Fig. 4). The abundance of these compounds indicates that unburned lubricating oils from road traffic exhaust are a significant contributor to aliphatic hydrocarbon contamination (Colombo et al., 1989; Simoneit,

Table 1

Values of alkane and PAH indexes obtained for Paris, Créteil and Coulommiers sites during each season

\begin{tabular}{|c|c|c|c|c|c|c|c|c|c|c|c|c|c|}
\hline & & \multicolumn{4}{|l|}{ Paris } & \multicolumn{4}{|l|}{ Créteil } & \multicolumn{4}{|c|}{ Coulommiers } \\
\hline & & Winter & Spring & Summer & Fall & Winter & Spring & Summer & Fall & Winter & Spring & Summer & Fall \\
\hline \multirow[t]{9}{*}{$\overline{\mathrm{AHs}}$} & $\mathrm{MAH}$ & $\mathrm{C} 29$ & $\mathrm{C} 29$ & $\mathrm{C} 29$ & $\mathrm{C} 29$ & $\mathrm{C} 29$ & $\mathrm{C} 29$ & $\mathrm{C} 29$ & $\mathrm{C} 27$ & $\mathrm{C} 29$ & $\mathrm{C} 27$ & C31 & $\mathrm{C} 27$ \\
\hline & LMW/HMW & 0.48 & 0.05 & 0.45 & 0.09 & 0.12 & 0.50 & 0.14 & 0.10 & 0.20 & 0.19 & 0.10 & 0.04 \\
\hline & $\mathrm{UCM} / \mathrm{R}$ & 10 & 2 & 3 & 7 & 6 & 2 & 5 & 6 & 1 & 2 & 3 & 2 \\
\hline & CPI & 1.30 & 2.19 & 3.31 & 3.46 & 1.38 & 2.52 & 4.46 & 3.67 & 1.21 & 5.60 & 7.23 & 8.10 \\
\hline & Odd/R & 0.54 & 0.68 & 0.73 & 0.77 & 0.57 & 0.69 & 0.81 & 0.78 & 0.54 & 0.84 & 0.87 & 0.89 \\
\hline & Prist/phyt & 0.70 & 0.98 & 1.10 & 1.64 & 0.80 & 0.99 & 0.85 & 0.83 & 1.01 & 0.96 & 1.53 & 1.29 \\
\hline & C18/phyt & 1.78 & 2.21 & 2.02 & 2.42 & 1.98 & 1.89 & 2.12 & 1.75 & 1.74 & 2.06 & 2.13 & 2.42 \\
\hline & $n$-alkanes/C16 & 38 & 443 & 28 & 166 & 168 & 43 & 109 & 208 & 89 & 114 & 156 & 577 \\
\hline & $\mathrm{C} 17 / \mathrm{C} 29$ & 0.40 & 0.03 & 0.40 & 0.05 & 0.08 & 0.71 & 0.17 & 0.08 & 0.12 & 0.14 & 0.06 & 0.04 \\
\hline \multirow[t]{3}{*}{ PAHs } & MPAH & Pyr & Pyr & Pyr & $\mathrm{P}$ & Pyr & Pyr & Pyr & Pyr & Fluo & Pyr & Fluo & Fluo \\
\hline & LMW/HMW & 0.48 & 0.20 & 0.45 & 1.04 & 0.51 & 0.30 & 0.52 & 0.23 & 0.42 & 1.06 & 0.44 & 0.04 \\
\hline & Alk./Par. & 0.35 & 0.05 & 0.11 & 0.04 & 0.34 & 0.08 & 0.15 & $0^{\mathrm{a}}$ & $0^{\mathrm{a}}$ & $0^{\mathrm{a}}$ & 0.03 & $0^{\mathrm{a}}$ \\
\hline
\end{tabular}

For aliphatic hydrocarbons (AHs): MAH=major aliphatic hydrocarbon; LMW/HMW=light molecular weight ( $\leq 20$ carbons)/high molecular weight ( $>20$ carbons); UCM=GC-SM unresolved complex mixture. For PAH: MPAH=major PAH; Pyr=pyrene; P=phenanthrene; Fluo=fluoranthene; LMW/HMW=light molecular weight (two-three rings)/high molecular weight (four-six rings); Alk./Par.=alkylated derivatives/parent compounds.

a Alkylated derivative/parent compound ratio was assumed equal to 0 when alkylated derivative value was under the detection limit. 
1985) in atmospheric deposition. In addition to resolved $n$-alkanes, gas chromatographic traces of aliphatic hydrocarbons are also characterised by an Unresolved Complex Mixture (UCM), i.e., the hump under the baseline on a chromatographic trace. The $\mathrm{UCM}$ is a complex mixture, extremely resistant to biodegradation, composed of numerous structurally complex isomers and a homologue of branched and cyclic alkanes (Aboulkassim and Simoneit, 1995). The UCM is a common feature of the gas chromatograms of crude oils and some refined products such as lubricating oils (Colombo et al., 1989; Gough and Rowland, 1990; Gough et al., 1992). Therefore, the relative importance of UCM, expressed as the ratio of unresolved to resolved compounds ( $\mathrm{UCM} / \mathrm{R})$, is commonly used as a diagnostic criterion for pollutant origins. In this work, depending on the seasons, $\mathrm{UCM} / \mathrm{R}$ ratio values range from 2 to 10 , from 2 to 7 and from 1 to 3 at Paris, Créteil and Coulommiers, respectively (Table 1). These results confirm that at Paris, and to a lesser extent, at Créteil, petroleum inputs contribute to the aliphatic hydrocarbon contamination of bulk deposition. On the contrary, as previously highlighted using $n$-alkane distributions, these petroleum inputs are negligible in the semiurban area, at Coulommiers.

An evolution of the aliphatic hydrocarbon fingerprints throughout the year has also been observed at the three sites. This seasonal variability is illustrated by the fluctuation of (1) the odd carbon-numbered $n$ alkane predominance and (2) the UCM abundance. The odd predominance is quantitatively formulated by the odd/R ratio (Fig. 5), i.e., the mass ratio of odd carbon-numbered $n$-alkanes to total resolved aliphatic hydrocarbons. For the three sites, the odd/R ratios display similar seasonal patterns. Values are low during the winter period-ranging from 0.46 to 0.63 -reflecting the low relative contribution of biogenic sources during winter. These ratios strongly increase during spring until the values reach 0.78 to 0.88 and remain quite constant during the summer and fall periods. This trend indicates a higher relative contribution of biogenic sources during the spring, summer and fall seasons, when plants are more active. In urban areas, the relative abundance of UCM also exhibits seasonal patterns (Fig. 5). The UCM/R ratios show quite high values during the cold period and lower values during the warm period. High values obtained during winter (median values $=10$ and 6 at Paris and Créteil, respectively; Table 1), and to a lesser extent, during fall (median values $=7$ and 6 at Paris and Créteil, respectively; Table 1) reflect a quite strong contribution of aliphatic hydrocarbons from petrogenic sources during the cold period. Conversely, low values obtained during spring-summer seasons (median values $=2-3$ and $6-2$ at Paris and Créteil, respectively; Table 1) confirm the low contribution of petrogenic inputs compared to biogenic inputs during the warm period.

3.2.1.2. Aromatic hydrocarbons. The 16 individual parent PAHs of the priority list of the U.S.-EPA and their alkylated derivatives are determined in particulate atmospheric deposition. Distributions of parent PAHs in particulate atmospheric fallout collected at the three sites during the winter, spring, summer and fall quarters are illustrated in Fig. 6 and values of origin indexes are summarised in Table 1. First, whatever the site or the season considered, aromatic distribution patterns are characterised by a dominance
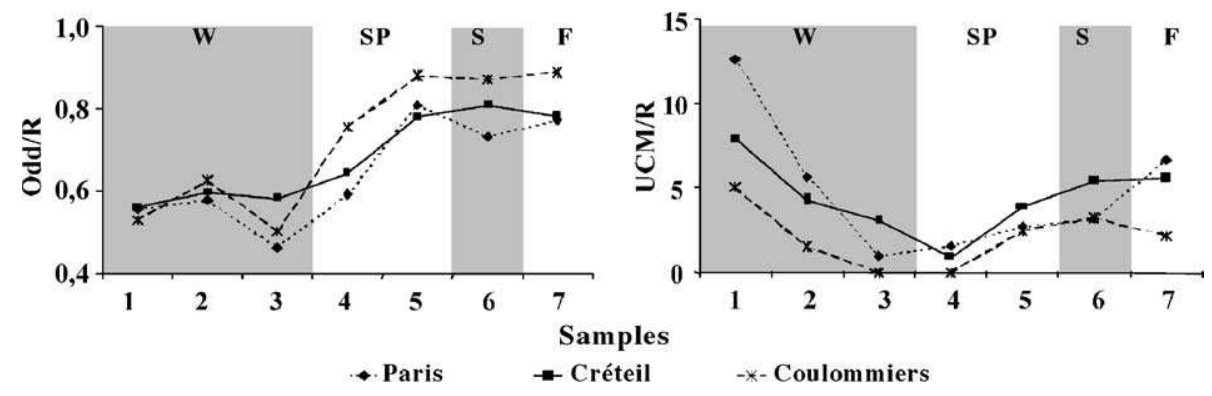

Fig. 5. Temporal variation of odd/R and UCM/R ratios (see text for ratio definition) at Paris, Créteil and Coulommiers sites from December 2001 to October 2002. The number of sampling periods during each season depended on the rainfall amount of the considered seasons, which are presented by different layers ( $\mathrm{W}=$ winter; $\mathrm{SP}=$ spring; $\mathrm{S}=$ summer; $\mathrm{F}=$ fall). 

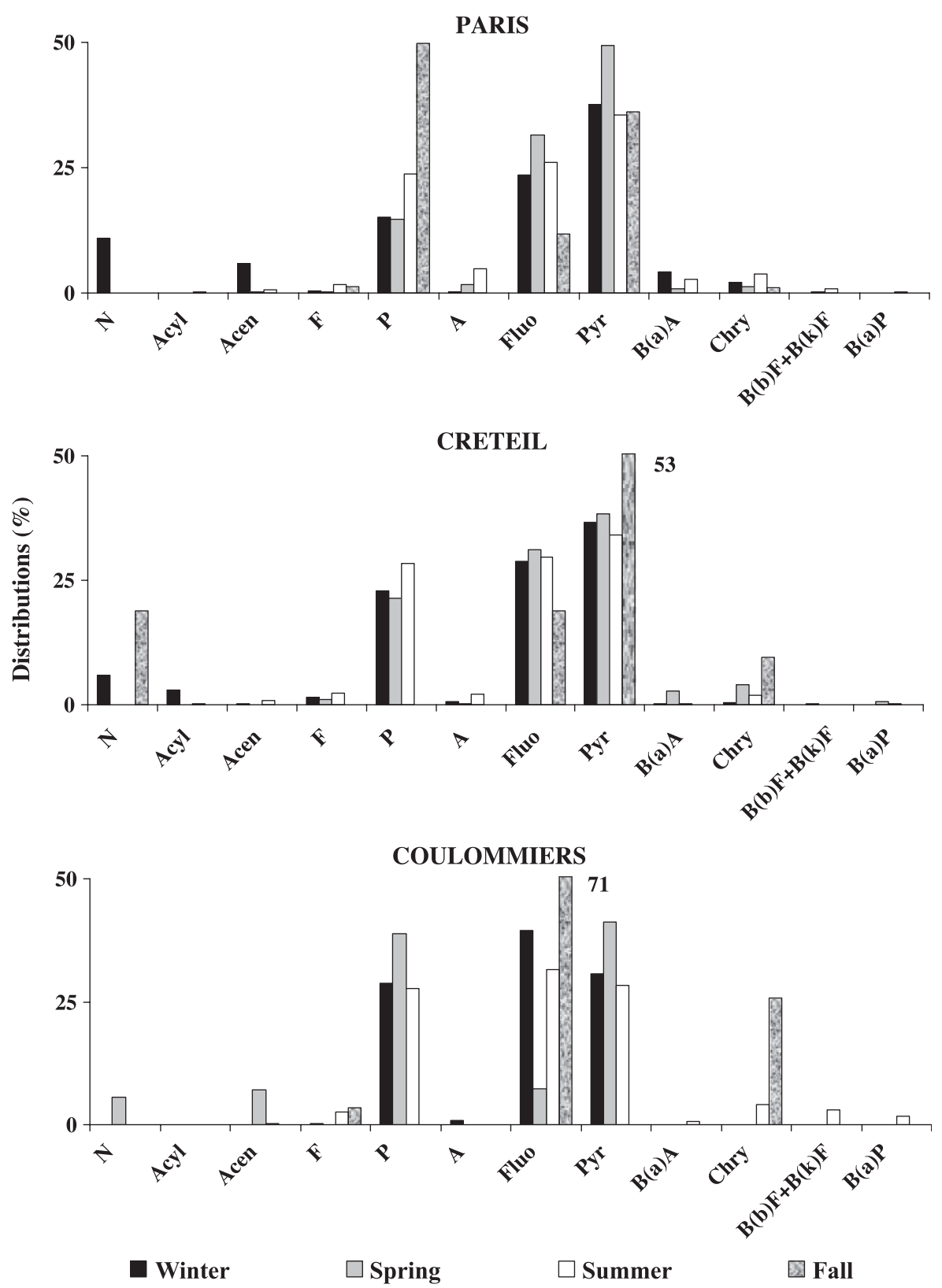

$\mathrm{N}=$ naphthalene, $\mathrm{Acyl}=$ acenaphthylene, Acen=acenaphthene, $\mathrm{F}=$ fluorene, $\mathrm{P}=$ phenanthrene, $\mathrm{A}=$ anthracene, Fluo=fluoranthene, $\mathrm{Pyr}=$ pyrene, $\mathrm{B}(\mathrm{a}) \mathrm{A}=$ benzo $[a]$ anthracene, Chry=chrysene, $\mathrm{B}(\mathrm{k}) \mathrm{F}=$ benzo $[k]$ flouranthene, $\mathrm{B}(\mathrm{b}) \mathrm{F}=$ benzo $[b]$ fluoranthene, $\mathrm{B}(\mathrm{a}) \mathrm{P}=$ benzo $[a]$ pyrene.

Fig. 6. PAH distributions in particulate atmospheric deposition collected at Paris, Créteil and Coulommiers during each season.

of heavy PAHs (four to six aromatic rings). Indeed, except for the cases of Paris in fall and Coulommiers in spring, all LMW/HMW PAH ratios are below 0.5 (Table 1). This predominance of heavy compounds indicates a pyrolytic origin for PAH pollution because many authors have reported that the petrogenic contamination is characterised by the abundance of lower molecular weight PAHs, while higher molecular 
weight PAHs dominate in the pyrolytic contamination distribution (Soclo et al., 2000; Wang et al., 1999; Yang et al., 1998; Zheng and Wan, 1997). Second, phenanthrene (P), fluoranthene (Fluo) and pyrene (Pyr) are always identified as the most abundant compounds (Fig. 6). According to the seasons, their sum accounts for $76-98 \%, 72-92 \%$ and $71-99 \%$ of total PAHs at Paris, Créteil and Coulommiers, respectively. The great predominance of these three compounds confirms the pyrolytic origin of aromatic pollutants in atmospheric deposition because they are commonly considered as typical pyrogenic products derived from high temperature condensation of lower molecular weight aromatic compounds (Khalili, 1995; Soclo et al., 2000). The impact of pyrolytic contamination is also suggested by the presence of chrysene (Chry) and benzo $[a]$ anthracene $(\mathrm{BaA})$, which are considered as markers of combustion processes (Moreda et al., 1998; Soclo et al., 2000). In order to distinguish between pyrolytic and petrogenic origins, the P/A and Fluo/Pyr concentration ratios can also be used. The P/A ratio is temperature-dependent with high temperature processes being characterised by low P/A values and petrogenic contamination leading to much higher $\mathrm{P} / \mathrm{A}$ values. Therefore, two different categories have been defined: $\mathrm{P} / \mathrm{A}>10$ for the petrogenic sources and $\mathrm{P} / \mathrm{A}<10$ for the dominance of pyrolytic sources (Budzinski et al., 1997). Similar considerations can be applied to the Fluo/Pyr ratio. Concerning this latter index, values above unity indicate that contamination by PAHs arises from combustion processes whereas values below unity indicate a petrogenic origin. These ratios suggest that atmospheric PAHs do not only originate from pyrolytic processes. Indeed, more than $90 \%$ of $\mathrm{P} / \mathrm{A}$ and Fluo/Pyr ratio values are above 10 and below unity, respectively, underlining the impact of petrogenic sources. The presence of alkylated derivatives in both urban sites, underlined by the alkylated derivative/parent compound ratios ranging from 0.04 to 0.35 and from 0 to 0.34 at Paris and Créteil, respectively, confirms the contribution of petrogenic inputs to the atmospheric pollution. Indeed, PAHs from petrogenic inputs are generally abundant in alkylated homologues relative to their parent compounds, while combustion of fossil fuels yields PAHs generally poor in alkylated homologues (Yunker et al., 1996; Zheng and Wan, 1997). Finally, throughout the year, the aromatic pollution in atmospheric deposition in the whole "Ile-de-France" region comes from a combination of petrogenic and pyrolytic inputs. The pyrolytic origin in this region may be linked to the high density of combustion sources in the Paris suburbs. Indeed, Paris suburbs have heavy road traffic, and consequently, diesel- and gasoline-powered vehicles emit great quantities of PAHs in the environment. Besides these mobile sources, aromatic compounds are introduced in the environment through contamination by various kinds of fixed sources such as residential heating, industrial plants and industrial waste incinerators. Petrogenic contamination in atmospheric deposition may be linked to the emission of unburned lubricating oils by road traffic exhaust.

\subsubsection{Metals fingerprint variability}

3.2.2.1. Al and Fe. The distribution of $\mathrm{Al}$ and $\mathrm{Fe}$ shows that the relative amount of $\mathrm{Fe}$ is highest at Paris centre. Values of the $\mathrm{Fe} / \mathrm{Al}$ ratio range from 1.99 to 2.10, from 1.36 to 1.82 and from 0.99 to 1.53 at Paris, Créteil and Coulommiers, respectively (Table 2). Fe/ $\mathrm{Al}$ ratios in the Earth's crust are variable, depending on chemical enrichments. Consequently, different ratios for the upper continental crust are reported. For example, Wedepohl (1995) found 0.40 for the Fe/ Al ratio while Taylor and McLennan (1995) reported 0.84. The Fe/Al ratios measured at Paris, Créteil and Coulommiers are higher than $\mathrm{Fe} / \mathrm{Al}$ ratios of pure crustal sources, indicating that both elements contained in the acid-soluble fraction of particles coming from atmospheric deposition have an anthropogenic source. At the Coulommiers site, the influence of crustal particles containing $\mathrm{Al}$ and $\mathrm{Fe}$ is enhanced because the ratios obtained at this location are closer to the Earth's crustal ratio, i.e., 0.84 (Taylor and McLennan, 1995). Concerning the seasonal variation, an increase of $\mathrm{Fe} / \mathrm{Al}$ ratios appears during fall and winter at both urban sites. Such changes indicate an

Table 2

Values of $\mathrm{Fe} / \mathrm{Al}$ ratios obtained for Paris, Créteil and Coulommiers sites during each season

\begin{tabular}{lllll}
\hline & Winter & Spring & Summer & Fall \\
\hline Paris & 1.99 & 1.85 & 1.97 & 2.10 \\
Créteil & 1.82 & 1.76 & 1.36 & 1.71 \\
Coulommiers & 0.99 & 1.19 & 1.28 & 1.53 \\
\hline
\end{tabular}


increase of Fe atmospheric loads probably due to the occurrence of the residential heating in winter, and to a lesser extent, in fall.

\subsubsection{THMs. Whatever site or season is considered,} the THM relative abundance has the same global pattern. Indeed, $\mathrm{Zn}$ is identified as the most abundant element (Fig. 7). Its relative abundance ranges from $42 \%$ to $51 \%$, from $29 \%$ to $42 \%$ and from $38 \%$ to $50 \%$ at Paris, Créteil and Coulommiers, respectively. Other main elements, for which the relative abundance ranges between $2 \%$ and $30 \%$, decrease in the following order $\mathrm{Cu} \geq \mathrm{Mn}>\mathrm{Pb} \approx \mathrm{Ba} \approx \mathrm{Sr}>\mathrm{Ti}$. The six remaining elements $(\mathrm{Cd}, \mathrm{Co}, \mathrm{Cr}, \mathrm{Ni}, \mathrm{V}$ and $\mathrm{Sb})$ exhibit a relative abundance below $2 \%$. The seasonal pattern of heavy metal distribution does not show a clear difference at the urbanised sites. Such an HM distribution pattern is likely to reflect the occurrence of the same sources through the year in urban areas. At the Coulommiers site, although the global pattern of the distribution does not change, the $\mathrm{Mn}$ and $\mathrm{Cu}$ relative distributions increase during the spring and summer and summer
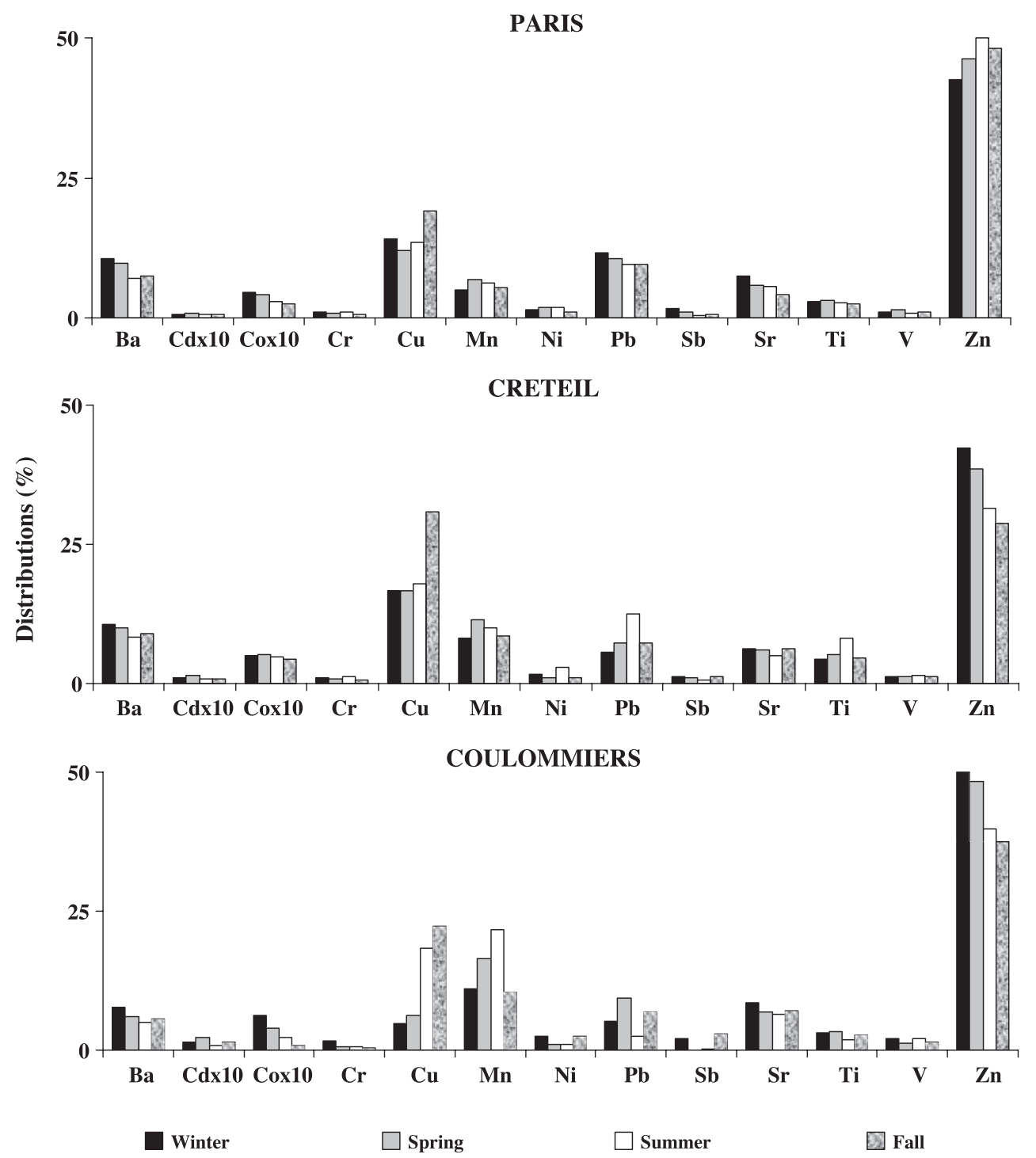

Fig. 7. Trace heavy metal distribution in bulk deposition collected at Paris, Créteil and Coulommiers during each season. 
and fall periods, respectively, while the $\mathrm{Pb}$ relative distribution decreases during the summer period. It seems that the increase of crustal sources and agricultural activities during these periods locally influence the atmospheric deposition of $\mathrm{Mn}$ and $\mathrm{Cu}$, respectively. The decrease of $\mathrm{Pb}$ can be attributed to the decrease of one of the sources of this element, e.g., road traffic (Sternbeck et al., 2002; Weckwerth, 2001), because the air mass trajectories did not change at this location during the whole year (the wind blew mainly from the west direction during the whole year), avoiding long-range transport influences.

To further identify common sources for pollutionderived trace elements, principal components analysis (PCA) is performed with retention of principal components $(\mathrm{PC})$ having eigenvalues $>1$. For each site, six factors are studied and Table 3 lists element loadings and explains the variance for each factor. Loads $<0.1$ are discarded and the significant values $(>0.5)$ are printed in bold characters. The PCA shows that six factors are needed to explain $89 \%, 89 \%$ and $92 \%$ of the total variance at Paris, Créteil and Coulommiers, respectively. Moreover, it appears that for several elements, two or three factors have loading values $>0.1$ and even $>0.3$, showing that, generally, trace elements have several potential sources, making the investigation of origin more difficult. The first factor that explains most of the variance (ranging between $36 \%$ and $39 \%$ for all sites) has high loadings for most of the elements. At the Paris location, the latter comprises elements such as $\mathrm{Ca}, \mathrm{Ba}, \mathrm{Ti}, \mathrm{Cr}, \mathrm{Mn}$, $\mathrm{Fe}, \mathrm{Al}, \mathrm{Pb}$, and to a lesser extent, $\mathrm{K}, \mathrm{Rb}, \mathrm{Sr}, \mathrm{V}, \mathrm{Co}, \mathrm{Ni}$, $\mathrm{Cd}$ and $\mathrm{P}$. At the Créteil site, the same result is obtained because the first factor has high loads for $\mathrm{Ca}$,

Table 3

Factor analysis on atmospheric bulk deposition fluxes dataset

\begin{tabular}{|c|c|c|c|c|c|c|c|c|c|c|c|c|c|c|c|c|c|c|}
\hline & \multicolumn{6}{|l|}{ Paris } & \multicolumn{6}{|l|}{ Créteil } & \multicolumn{6}{|c|}{ Coulommiers } \\
\hline & Fac 1 & Fac 2 & Fac 3 & Fac 4 & Fac 5 & Fac 6 & Fac 1 & Fac 2 & Fac 3 & Fac 4 & Fac 5 & Fac 6 & Fac 1 & Fac 2 & Fac 3 & Fac 4 & Fac 5 & Fac 6 \\
\hline $\mathrm{Na}$ & - & 0.145 & - & - & 0.606 & - & - & 0.490 & 0.101 & 0.192 & - & - & - & 0.199 & - & 0.508 & - & - \\
\hline K & 0.456 & 0.120 & 0.338 & - & - & - & 0.491 & - & 0.340 & - & - & - & 0.896 & - & - & - & - & - \\
\hline $\mathrm{Rb}$ & 0.466 & 0.304 & - & - & - & - & - & 0.117 & 0.244 & 0.421 & - & - & 0.806 & $6-$ & - & - & - & - \\
\hline $\mathrm{Mg}$ & - & - & - & - & 0.142 & 0.712 & 0.395 & 0.332 & - & 0.189 & - & - & 0.911 & - & - & - & - & - \\
\hline $\mathrm{Ca}$ & 0.505 & - & - & 0.338 & - & - & 0.774 & - & 0.116 & - & - & - & 0.917 & $7-$ & - & - & - & - \\
\hline $\mathrm{Sr}$ & 0.433 & 0.291 & - & - & - & 0.137 & 0.734 & - & - & - & - & - & 0.951 & $1-$ & - & - & - & - \\
\hline $\mathrm{Ba}$ & 0.550 & 0.126 & - & 0.154 & - & - & 0.741 & 0.150 & - & - & - & - & 0.672 & 0.108 & 0.118 & - & - & - \\
\hline $\mathrm{Ti}$ & 0.893 & - & - & - & - & - & - & 0.678 & - & - & - & - & - & 0.924 & - & - & - & - \\
\hline $\mathrm{V}$ & 0.396 & 0.194 & - & - & - & - & 0.233 & - & - & - & 0.304 & 0.106 & 0.786 & $6-$ & - & - & - & - \\
\hline $\mathrm{Cr}$ & 0.554 & - & 0.269 & - & - & - & 0.365 & - & 0.334 & - & 0.154 & - & - & 0.301 & 0.317 & - & 0.103 & - \\
\hline $\mathrm{Mn}$ & 0.739 & - & - & - & - & - & 0.900 & - & - & - & $-\quad-$ & - & 0.973 & - & - & - & - & - \\
\hline $\mathrm{Fe}$ & 0.729 & - & - & - & - & - & 0.872 & - & - & - & - & - & 0.279 & 0.674 & - & - & - & - \\
\hline $\mathrm{Al}$ & 0.770 & - & - & - & - & - & 0.276 & 0.472 & - & 0.102 & - & - & - & 0.869 & - & - & - & - \\
\hline Co & 0.370 & 0.344 & - & - & 0.147 & - & 0.666 & - & - & 0.148 & - & - & 0.126 & 0.233 & - & - & 0.170 & - \\
\hline $\mathrm{Ni}$ & 0.458 & 0.136 & - & 0.201 & - & - & 0.148 & - & 0.338 & - & - & 0.296 & 0.121 & - & 0.494 & 0.141 & - & - \\
\hline $\mathrm{Cu}$ & 0.199 & - & - & 0.579 & 0.108 & - & 0.388 & - & 0.448 & - & - & - & 0.588 & - & - & - & - & - \\
\hline $\mathrm{Zn}$ & 0.226 & - & - & 0.498 & - & - & 0.634 & - & - & - & - & - & 0.752 & - & 0.183 & - & - & - \\
\hline $\mathrm{Sn}$ & 0.127 & - & 0.333 & - & 0.109 & - & 0.183 & 0.225 & - & - & 0.347 & - & 0.283 & - & 0.572 & - & - & - \\
\hline $\mathrm{Sb}$ & - & 0.788 & - & - & - & - & - & 0.456 & - & - & - & - & - & 0.154 & - & 0.465 & 0.102 & - \\
\hline $\mathrm{Zr}$ & 0.229 & 0.347 & 0.301 & - & - & - & 0.209 & - & - & 0.352 & - & 0.222 & 0.516 & 0.105 & 0.297 & - & - & - \\
\hline $\mathrm{Pb}$ & 0.683 & - & - & - & - & - & 0.321 & - & 0.337 & - & 0.109 & - & - & 0.105 & 0.121 & - & 0.275 & 0.118 \\
\hline $\mathrm{Cd}$ & 0.441 & 0.157 & - & 0.177 & - & - & 0.593 & - & - & 0.112 & 0.167 & - & 0.298 & - & - & 0.135 & 0.134 & 0.142 \\
\hline $\mathrm{Ag}$ & 0.171 & 0.176 & 0.401 & - & 0.104 & - & - & 0.155 & 0.166 & 0.286 & - & - & - & - & - & - & 0.357 & 0.296 \\
\hline $\mathrm{P}$ & 0.487 & 0.205 & - & 0.104 & 0.100 & - & 0.269 & - & 0.433 & - & 0.144 & - & 0.923 & - & - & - & - & - \\
\hline $\mathrm{Li}$ & 0.224 & 0.350 & 0.396 & - & - & - & - & 0.561 & - & 0.241 & - & - & 0.739 & - & - & - & 0.101 & - \\
\hline $\mathrm{S}$ & 0.240 & 0.127 & 0.499 & - & - & - & - & 0.858 & - & - & - & - & 0.856 & $6-$ & - & - & - & - \\
\hline $\mathrm{Si}$ & - & 0.330 & 0.545 & - & - & - & 0.344 & 0.517 & - & - & - & - & 0.105 & 0.751 & - & - & - & - \\
\hline Eigenvalues & 10.5 & 4.4 & 3.5 & 2.5 & 1.9 & 1.4 & 9.7 & 5.4 & 3.2 & 2.6 & 2.0 & 1.1 & 9.7 & 5.4 & 3.2 & 2.6 & 2.0 & 1.1 \\
\hline$\%$ Variance & 39 & 16 & 13 & 9 & 7 & 5 & 36 & 20 & 12 & 10 & 7 & 4 & 36 & 20 & 12 & 10 & 7 & 4 \\
\hline
\end{tabular}


$\mathrm{Sr}, \mathrm{Ba}, \mathrm{Mn}, \mathrm{Fe}, \mathrm{Co}, \mathrm{Zn}$ and $\mathrm{Cd}$. It appears that a unique source specification for the first factor is not obvious. THMs may come from many different sources in urbanised areas, including vehicle emissions, industrial discharges and other activities. For example, $\mathrm{Ba}, \mathrm{Cd}, \mathrm{Cu}, \mathrm{Pb}, \mathrm{Sb}$ and $\mathrm{Zn}$ appear in gasoline, car components, oil lubricants, industrial and incinerator emissions (Alloway, 1990). Thus, a mix of numerous source rejects seems to occur in the urban atmosphere because many elements are correlated to the same factor. The same result appears for the Coulommiers site, which has fewer anthropogenic sources: the first factor has high loads for many elements ( $\mathrm{K}, \mathrm{Rb}, \mathrm{Mg}, \mathrm{Ca}, \mathrm{Sr}, \mathrm{Ba}, \mathrm{V}, \mathrm{Cr}$, etc.). This result, associated with the wind conditions, blowing mainly from the west direction (Garban et al., 2002), shows that this location is situated under the plume of the Paris suburb activities, which have a significant influence on atmospheric deposition at this site.

With respect to other factors of the PCA, at the Paris location, high loads are found for $\mathrm{Si}, \mathrm{S}, \mathrm{Li}, \mathrm{Ag}$, $\mathrm{Sn}, \mathrm{Cr}$ and $\mathrm{K}$ on factor 3. Atmospheric $\mathrm{Si}$ is commonly considered a crustal element, but its current association with $\mathrm{S}$ and $\mathrm{Cr}$ and the fact that only the acid-soluble fraction is analysed suggest that emissions from incinerators and coal combustion may contribute to atmospheric Si in this region (Querol et al., 1996). At the Créteil site, these sources are represented by factor 2, which has high loads in $\mathrm{Si}$, $\mathrm{S}, \mathrm{Li}, \mathrm{Sb}, \mathrm{Ti}, \mathrm{Ca}$ and $\mathrm{Na}$. At the Coulommiers site, the crustal influence of soil dust resuspension can be observed on factor 2, which has significantly high loads for $\mathrm{Si}, \mathrm{Al}$ and $\mathrm{Fe}$. Thus, atmospheric deposition in this area is under the influence of crustal dust resuspension as well as anthropogenic activities.

\section{Conclusion}

Atmospheric bulk deposition was sampled at three sites in the Paris area during 11 months. Collected samples were analysed for 27 aliphatic hydrocarbons, 16 aromatic hydrocarbons and 15 heavy metals using a combination of GC-SM and ICP-AES methods. Quantitative data on atmospheric pollutants show the difference in atmospheric deposition between the urban and the semiurban sites in the "Ile-de-France" region, France. Presumably, the high density of urban and industrial sources in the Paris suburb is responsible for the high atmospheric deposition fluxes of all measured pollutants (aliphatic hydrocarbons, PAHs and heavy metals), even elements usually considered as crustal ( $\mathrm{Al}$ and $\mathrm{Fe}$ ). The seasonal variability shows the increase of hydrocarbons, i.e., both aliphatic and aromatic, during fall and winter, while $\mathrm{Al}$ and $\mathrm{Fe}$ present higher deposition fluxes during spring and summer. This latter is most probably induced by the increase of atmospheric dust loads, whereas the winter hydrocarbon increase is attributed to residential heating. Trace heavy metals exhibit no significant seasonal trend because their sources are relatively constant throughout the year. The qualitative study performed on atmospheric deposition data sheds light on the main sources of these pollutants. Aliphatic fingerprints suggest a marked contribution of biogenic inputs to aliphatic contamination in the whole Paris region and slight petroleum inputs in urban areas. Whatever site or season is considered, aromatic fingerprints are characterised by a great dominance of P, Fluo and Pyr. This predominance, associated with the ratio values of P/A and Fluo/Pyr, suggests the mixture of petrogenic and pyrolytic contamination in the whole "Ile-de-France" region. The heavy metal source investigation appears to be more difficult than with hydrocarbons because for inorganic elements, specific ratios are less developed. However, such study underlines the presence of anthropogenic $\mathrm{Al}$ and Fe sources in urban areas. The PCA shows that a mix phenomenon, occurring in urban atmospheres, is propagated over the whole region according to meteorological conditions.

\section{Acknowledgements}

Authors are grateful to J.-L. Colin, E. Bon and M. Lachaud for their scientific support. This work was financially supported by the PIREN-Seine Research Program (CNRS GDR 1067). The cooperation of P. Ansart (Cemagref) and the headmistress of the Ste Geneviève school (Paris) is fully acknowledged.

\section{References}

Aboulkassim T, Simoneit B. Aliphatic and aromatic hydrocarbons in particulate fallout of Alexandria, Egypt: sources and applications. Environ Sci Technol 1995;29:2473-83. 
Alloway BJ. Heavy metals in soils: their origins. Chemical behaviour \& bioavailability. London: Wiley John and Sons; 1990. 339 pp.

Azimi S, Ludwig A, Thévenot DR, Colin J-L. Trace metal determination in total atmospheric deposition in rural and urban areas. Sci Total Environ 2003;308:247-54.

Baek SO, Field RA, Goldstone ME, Kirk PWW, Lester JN, Perry R. A review of atmospheric polycyclic aromatic hydrocarbons: sources, fate and behaviour. Water Air Soil Pollut 1991;60: $279-300$.

Bilos C, Colombo JC, Skorupka CN, Rodriguez Presa MJ. Sources, distribution and variability of airborne trace metals in La Plata City area, Argentina. Environ Pollut 2001;111:149-58.

Bomboi MT, Hernandez A. Hydrocarbons in urban runoff: their contribution to the wastewaters. Water Res 1991;25:557-65.

Bouloubassi I, Saliot A. Investigation of anthropogenic and natural organic imputs in estuarine sediments using hydrocarbon markers (NAH, LAB, PAH). Oceanol Acta 1993;16:145-61.

Budzinski H, Jones I, Bellocq C, Piérard P, Garrigues P. Evaluation of sediment contamination by polycyclic aromatic hydrocarbons in the Gironde estuary. Mar Chem 1997;58:85-97.

Colin JL, Jaffrezo JL, Gros JM. Solubility of major species in precipitation: factors of variation. Atmos Environ 1990;25A: 537-44.

Colombo JC, Pelletier E, Brochu C, Khalil M. Determination of hydrocarbon sources using $n$-alcane and polyaromatic hydrocarbon distribution indexes Case study: Rio de la Plata estuary, Argentina. Environ Sci Technol 1989;23:888-94.

Colombo JC, Landoni P, Bilos C. Sources, distribution and variability of airborne particles and hydrocarbons in La Plata area, Argentina. Environ Pollut 1999;104:305-14.

Cortes DR, Basu I, Sweet CW, Hites RA. Temporal trends in and influence of wind on PAH concentrations measured near the Great Lakes. Environ Sci Technol 2000;34:356-60.

Desboeufs K, Losno R, Colin JL. Factors influencing aerosol solubility during cloud processes. Atmos Environ 2001;35: 3529-37.

Evans KM, Gill RA, Robotham PWJ. The source, composition and flux of PAH in sediments of the river Derwent, Derbyshire, UK. Water Air Soil Pollut 1990;51:1-12.

Garban B, Blanchoud H, Motelay-Massei A, Chevreuil M, Ollivon D. Atmospheric bulk deposition of PAHs onto France: trends from urban to remote sites. Atmos Environ 2002; 36:5395-403.

Garnaud S, Mouchel J-M, Chebbo G, Thévenot DR. Caractérisation des retombées atmosphériques de métaux traces en milieu urbain. TSM 2001;5:30-40.

Gogou A, Stratigakis N, Kanakidou M, Stephanou EG. Organic aerosols in Eastern Mediterranean: components source reconciliation by using molecular markers and atmospheric back trajectories. Org Geochem 1996;25:79-96.

Golomb D, Ryan D, Eby N, Underhill J, Zemba S. Atmospheric deposition of toxic onto Massachusetts Bay: I. Metals. Atmos Environ 1997;31:1349-59.

Gough MA, Rowland SJ. Characterization of unresolved complex mixtures of hydrocarbons in petroleum. Nature 1990;344: $648-50$.
Gough MA, Rhead MM, Rowland SJ. Biodegradation studies of unresolved complex mixture of hydrocarbons: model UCM hydrocarbons and aliphatic UCM. Org Geochem 1992;18:17-22.

Guieu C, Chester R, Nimmo M, Martin J-M, Guerzoni S, Nicolas $\mathrm{E}$, et al. Atmospheric inputs of dissolved and particulate metals to the northwestern Mediterranean. Deep-Sea Res 1997;44:655-74.

Halsall CJ, Coleman PJ, Jones KC. Atmospheric deposition of polychlorinated dibenzo- $p$-dioxins/dibenzofurans and polycyclic aromatic hydrocarbons (PAHs) in two UK cities. Chemosphere 1997;35:1919-31.

Injuk J, Van Grieken R, De Leeuw G. Deposition of atmospheric trace element into the North Sea: coastal, ship, platform measurements and model predictions. Atmos Environ 1998; 32:3011-25.

Kaya G, Tuncel G. Trace element and major ion composition of wet and dry deposition in Ankara, Turkey. Atmos Environ 1997; 31:3985-98.

Khalili NR. PAH fingerprints for coke ovens, diesel and gasoline engines, highway tunnels and wood combustion emissions. Atmos Environ 1995;29:533-42.

Kim G, Scudlark JR, Church TM. Atmospheric wet deposition of trace elements to Chesapeake and Delaware Bays. Atmos Environ 2000;34:3437-44.

Lang Q, Zhang Q, Jaffé R. Organic aerosols in the Miami area, USA: temporal variability of atmospheric particles and wet/dry deposition. Chemosphere 2002;47:427-41.

Lawlor AJ, Tipping E. Metals in bulk deposition and surface water at two upland locations in northern England. Environ Pollut 2003;121:153-67.

Maneux E, Grousset FE, Buat-Ménard P, Lavaux G, Rimmelin P, Lapaquellerie Y. Temporal patterns of the wet deposition of Z, $\mathrm{Cu}, \mathrm{Ni}, \mathrm{Cd}$ and $\mathrm{Pb}$ : the Arcachon lagoon (France). Water Air Soil Pollut 1999;114:95-120.

Manoli E, Vousta D, Samara C. Chemical characterisation and source identification/apportionment of fine and coarse air particles in Thessaloniki, Greece. Atmos Environ 2002;36: 949-61.

Moreda JM, Arranz A, Fdez De Betono S, Cid A, Arranz JF. Chromatographic determination of aliphatic hydrocarbons and polyaromatic hydrocarbons (PAHs) in a sewage sludge. Sci Total Environ 1998;220:33-43.

Ollivon D, Blanchoud H, Motelay-Massei A, Garban B. Atmospheric deposition of PAHs to an urban site, Paris, France. Atmos Environ 2002;36:2891-900.

Pacyna JM, Graedel TE. Atmospheric emissions inventories: status and prospects. Annu Rev Energy Environ 1995;20:265-300.

Park JS, Wade TL, Sweet S. Atmospheric distribution of poluycyclic aromatic hydrocarbons and deposition to Galveston Bay, Texas, USA. Atmos Environ 2001;35:3241-9.

Querol X, Lopez-Soler A, Fernandez-Turiel J-L, Juan R, Ruiz CR. Mobility of trace elements from coal and combustion wastes. Fuel 1996;75:821-38.

Rocher V, Azimi S, Moilleron R, Chebbo G. Biofilm in combined sewer: wet weather pollution source or/and dry weather pollution indicator? Water Sci Technol 2003;47:35-43. 
Sandroni V, Migon C. Atmospheric deposition of metallic pollutants over the Ligurian Sea: labile and residual inputs. Chemosphere 2002;47:753-64.

Schauer JJ, Rogge WF, Hildemann LM, Mazurek MA, Cass GR. Source apportionment of airborne particulate matter using organic compounds as tracers. Atmos Environ 1996;30:3837-55.

Scudlark JR, Conko KM, Church TM. Atmospheric wet deposition of trace elements to Chesapeake Bay: CBAD study year 1 results. Atmos Environ 1994;28:1487-98.

Simoneit BRT. Application of molecular marker analysis to vehicular exhaust for source reconciliation. Int J Environ Anal Chem 1985;22:203-33.

Simoneit BRT, Sheng G, Chen X, Fu J, Zhang J, Xu Y. Molecular markers study of extractable organic matter in aerosols from urban areas of China. Atmos Environ 1991;25A:2111-29.

Soclo HH, Garrigues P, Ewald M. Origin of polycyclic aromatic hydrocarbons (PAHs) in coastal marin sediments: case studies in Cotonou (Benin) and Aquitaine (France) areas. Mar Pollut Bull 2000;40:387-96.

Sternbeck J, Sjodin A, Andreasson K. Metal emissions from road traffic and the influence of resuspension-results from two tunnel studies. Atmos Environ 2002;36:4735-44.

Sweet CW, Weiss A, Vermette SJ. Atmospheric deposition of trace metals at three sites near the great lakes. Water Air Soil Pollut 1998;103:423-39.
Taylor SR, McLennan SM. The geochemical evolution of the continental crust. Rev Geophys 1995;33:241-65.

Wang Z, Fingas M, Landriault M, Sigouin L, Feng Y, Mullin J. Using systematic and comparative analytical data to identify the source of an unknown oil on contaminated birds. J Chromatogr 1997;775:251-65.

Wang Z, Fingas M, Page DS. Oil spill identification. J Chromatogr 1999;A843:369-411.

Weckwerth G. Verification of traffic emitted aerosol components in the ambiant air of Cologne (Germany). Atmos Environ 2001; 35:5525-36.

Wedepohl KH. The composition of the continental crust. Geochim Cosmochim Acta 1995;59:1217-32.

Yang HH, Lee WJ, Chen SJ, Lai SO. PAH emission from various industrial stacks. J Hazard Mater 1998;60:159-74.

Yunker MB, Snowdon LR, Macdonald RW, Smith JN, Fowler MG, Skibo DN, et al. Polycyclic aromatic hydrocarbon composition and potential sources for sediment samples from the Beaufort and Barents seas. Environ Sci Technol 1996;30:1310-20.

Zheng M, Wan T. Characterisation of the non volatile organic compounds in the aerosols of Hong Kong: identification, abundance and origin. Atmos Environ 1997;31:227-37. 